\title{
A social constitution of Europe?
}

\section{Tuori, Kaarlo}

Edward Elgar

2019-12

Tuori , K 2019 , A social constitution of Europe? in S Hänninen, K-M Lehtelä \& P Saikkonen

(eds) , The relational Nordic Welfare State . Edward Elgar, Cheltenham , pp. 138-160 . https://doi.org/10.4337/9781

http://hdl.handle.net/10138/315782

https://doi.org/10.4337/9781788974653.00016

cc_by_nc

acceptedVersion

Downloaded from Helda, University of Helsinki institutional repository.

This is an electronic reprint of the original article.

This reprint may differ from the original in pagination and typographic detail.

Please cite the original version. 
This is a draft chapter. The final version is available in The relational Nordic Welfare State edited by Sakari Hänninen, Kirsi-Maria Lehtelä and Paula Saikkonen, published in 2019, Edward Elgar Publishing https://doi.org/10.4337/9781788974653

The material cannot be used for any other purpose without further permission of the publisher, and is for private use only.

$<$ fresh page $><\mathrm{cn}>7 .<\mathrm{ct}>$ A social constitution of Europe?*

$<$ au $>$ Kaarlo Tuori

<a>THE MULTI-DIMENSIONAL EU CONSTITUTION

As the 'constitutional charter' of the European Union (EU), the Founding Treaties are bewildering reading for someone approaching them through the state template. Indeed, the general embarrassment among the citizenry when confronted with the substance of the abortive Constitutional Treaty in the mid-2000s has been identified as one of the reasons for its rejection in the French and Dutch referenda. The Treaties contain an abundance of provisions which do not pertain to the typical materia constitutionis of state constitutions, most conspicuously provisions on diverse policy fields. The European constitution is not only about European law and polity; it is also about European economy, European social welfare and European security.

State constitutions usually limit themselves to regulating the political and legal sub-systems of society. The political and juridical dimensions exist in the European constitution as well. In the political dimension, constitutional law regulates the EU as a polity, and in the juridical dimension, the EU legal system. But EU constitutional law also constitutionalizes sectoral fields which, at state level, are usually the province of ordinary policy-and lawmaking. In state constitutions, the basic 
premise is the universality of the political and legal claim to authority within state territory, the principle of comprehensive powers, as we can also put it. State constitutions follow a territorial principle of authority, and consequently, no sector-specific constitutional authorizations are needed. By contrast, the EU does not adhere to a territorial principle of authority but to a functional or substantive principle of authority. In accordance with the basic policy orientation of the EU, its juridical and political claim to authority is substantially (functionally) limited. Neither is the assumption of comprehensive powers valid for the European transnational polity and legal system; the principle of conferral substitutes for that of comprehensive powers. Not only must the European constitution provide the general juridical and political framework for sectoral policies, it must also set sectoral objectives and create sectoral competences. Consequently, the framing political and juridical constitutions are complemented by sectoral constitutions, such as economic, social and security constitutions. Furthermore, economic constitutionalization has produced a differentiation between two subfields: a microeconomic constitution, based on the Treaty of Rome but in important respects elaborated by the European Court of Justice (ECJ), and a macroeconomic one, based on the Maastricht provisions on the Economic and Monetary Union (EMU). The microeconomic constitution is centred on free movement and competition law, and focuses on the economic activity of individual economic actors. In turn, the macroeconomic constitution addresses macroeconomic objectives and policies.

European integration has primarily been an economic project, and in spite of the expansion of EU activities into new policy domains, economic integration still retains a dominant position. This has left its imprint on inter-dimensional relations within the European constitution. The economic constitution has benefited from a functional primacy with regard not only to the framing juridical 
and political constitutions but to other sectoral constitutions as well. Thus, the social policy provisions of the Treaty of Rome already had an economic rationale: they served the free movement of workers or secured a level playing field for the industries of different Member States. Still, the functional primacy of the European economic constitution should not be understood in absolute terms. Although owing their initial momentum to the economic constitution, in their further development, non-economic constitutional dimensions may have obtained at least partial independence from economic considerations. Signs of independence - or at least striving for independence - are detectable in the social constitution too. A model example of growing autonomy is offered by the way the Treaty of Rome provision on equal pay was progressively detached from its economic rationale and turned into a nucleus of EU antidiscrimination law. The gradual development of constitutional social rights also reflects an aspiration for independence, although cross-border social rights in particular owe much of their initial dynamics to the implications of the economic constitution. The free movement of workers has provided the impetus for the right to cross-border social security and the free movement of services has provided the impetus for the right to cross-border healthcare.

The at least partial independence of the social constitution points to yet another type of relations between constitutional dimensions: the relations of conflict. Increasing autonomy may lead to normative results which contradict the requirements of the economic constitution. Before the ECJ, such constitutional conflicts often assumed the guise of a contestation between different types of rights. Economic rights derived from free movement law may clash with social rights, or civil or political fundamental rights. In a standard constellation before the ECJ, the issue was whether the protection of other types of rights justified derogating from economic rights; reference can be 
made to such celebrated rulings of the ECJ as Omega and Schmidberger or Viking and Laval. ${ }^{1}$ The functional primacy of the economic constitution is obvious in the very posing of the issue; in conflicts of rights, what needs justification is restricting not a fundamental right but an economic right?

$<$ OIS THERE A EUROPEAN SOCIAL CONSTITUTION?

EU Treaty law contains provisions on social values and objectives, social policy competences and even social rights. Ever since the Treaty of Rome, social values and objectives have occupied a prominent place in 'surface-level' constitutional law, alongside economic objectives. The value basis of the EU, as defined in Art. 2 TEU, comprises values relevant for social policy, such as justice, solidarity and equality between men and women. Furthermore, Art. 3 TEU includes social objectives and, in defining economic objectives, refers to their social implications as well; it even introduces the term social market economy, familiar from German post-World War II debates. Ever since Rome, the Treaty has also included a Social Policy title, which was gradually amended into the shape it received in Lisbon wherein legislative competences, too, have been established. Social rights are a later addition; here the decisive breakthrough was only made with the Lisbon Treaty, which concurred with a constitutional status on the Charter of Fundamental Rights of the European Union (CFREU), including its Solidarity chapter.

Still, doubts have been raised about whether these provisions justify the talk of a social dimension in the European constitution. The doubts rest on two main grounds. For many observers, socially oriented Treaty provisions, as well as secondary legislation, are of a patchwork character and not 
animated by a coherent social policy view which would lend individual provisions the necessary degree of coherence. Secondly, the economic constitution has enjoyed, and to a large extent still enjoys, primacy over a putative social dimension. Unlike Treaty provisions on free movement and competition law - the core of the (micro)economic constitution - provisions on social policy have not enjoyed a direct effect in Member State courts. Macroeconomic constitutionalization - so the argument continues - has only added to the constitutional disparity between economic and social policy. I concede the pertinence of both arguments (the lack of a shared normative vision of social Europe and the subjugation of social policy considerations to the needs of economic integration). Yet, these facts tell not so much of the absence of a social constitution as they tell of two of its main characteristic features: the primacy of the national welfare state and the subordination of the social constitution to the economic constitution.

The European economic constitution has always relied on the presupposition of the existence of national redistributive mechanisms. National welfare policies have been a silent partner in European constitutionalism and must necessarily be included in a discussion of the European social constitution. The underlying assumption in Rome was that the Treaty would achieve its social goals through the increased economic prosperity which the common market would produce and which would then be redistributed through national welfare mechanisms. The macroeconomic constitution, the foundations of which were laid in Maastricht, also presupposes national welfare policies. The Europeanization of monetary policy has increased the importance of fiscal policy as a key national instrument for adjusting to asymmetric internal and external shocks. Of particular importance are so-called automatic stabilizers, that is, counter-cyclically altering revenues and expenditures, such as taxes and welfare spending. 
In European debates, social and fiscal policies are often seen as inseparable. If one remains with the Member States, the other one should remain as well. And, correspondingly: if one were to be transferred to the European level, the other should follow. But in figuring out which policy field should take the lead, positions have diverged. In debates on the EMU, the economists - those who emphasized that monetary union was impossible without economic union - pointed to the need for Europeanized fiscal policy and argued that this would imply the Europeanization of social policy as well. In turn, those who wanted to retain national welfare regimes under national sovereignty were well aware that this required fiscal policy sovereignty too. The Lisbon ruling of the German Constitutional Court ${ }^{2}$ is a token of the jealousy with which Member States have guarded their sovereignty in social policy, especially as regards core welfare services with a redistributive effect, such as social security and healthcare. In line with fiscal policy, Treaty revisions have retained social policy under Member State sovereignty. The primacy of the national welfare state in the core welfare services has been explicitly enshrined in Treaty law, as has the principle of European neutrality with regard to national welfare models. Accordingly, ever since the Treaty of Rome, provisions on social policy have emphasized soft measures of coordination, instead of legislative competences.

Overall, a social dimension can be discerned in European constitutionalism, but only if we include the national level in the discussion. In addition, those claiming that the EU lacks a unifying normative social policy vision have mainly focused on the core fields of national welfare policy, namely social security and healthcare. Yet, arguably, the particular contribution of the EU social legislator has concentrated on areas which, in the national setting, lie on the fringes of the welfare 
state, on what Hans-W. Micklitz has called European regulatory private law. And, as Micklitz contends, European regulatory private law might be imbued with a definite normative vision of its own, a particular notion of justice which Micklitz (2011a) terms access justice. Two basic tensions permeate the social dimension of European constitutionalism. On the one hand, the primacy of the national welfare state is, with difficulty, reconcilable with the prevalence of the economic constitution. On the other hand, European access justice confronts the solidaristic social justice underpinning national welfare regimes, a confrontation that may have conflictual consequences.

$<$ a WHY THE PRIMACY OF THE NATIONAL WELFARE STATE?

Social policy, especially in the key areas of social security and healthcare, is about redistribution based on value choices, and such redistribution entails an enhanced need for democratic legitimacy. As long as the EU is afflicted by a democratic deficit, this need can only be met at the national level. A shift of emphasis in social policy from the national to European level would only aggravate the existing legitimacy deficit. Moreover, it could jeopardize the overall legitimacy of national political regimes which, in post-war Western Europe, has largely derived from the fair (re)distribution of increasing prosperity through welfare state mechanisms. As the democratic input legitimacy of the Union is mainly guaranteed by national democratic procedures, Member State legitimacy problems would have repercussions at the European level as well.

Redistributive welfare policy reflects a solidaristic notion of social justice. Solidarity as a moral or ethical principle is intimately linked to solidarity as a sociological fact. Redistributive social policy draws on and presupposes solidarity among the members of the polity. Solidarity, in the 
sociological sense of the term, builds on common history, values and identity. In spite of increasing and intensifying cross-boundary ties among European citizens, up to now the necessary cultural basis for such solidarity has only existed at the national level. This has inevitably made the postWorld War II welfare state a national project. In turn, cultural divergences and particular national historical trajectories and traditions account for differences in welfare state ideologies and normative commitments, and for different specifications of social justice and its implications. Member State welfare regimes manifest varying perceptions of the respective tasks of the state, the market and the third sector - as well as of the respective weight of financial transfers and public services in kind - as instruments of social policy.

The relative homogeneity among the six original Bismarckian welfare states has long since been broken, and it is futile to search for a uniform European Social Model that is shared by the Member States. Scholars have proposed diverse groupings, starting from Gøsta Esping-Andersen's (1990) now classic division into Anglo-Saxon liberal, Central and Southern European corporatist, and Nordic social democratic welfare states. Cultural diversity, resulting in bounded solidarities and divergent conceptions of social policy, goes a long way to explaining the tenacity with which Member States try to shield their welfare regimes, both within the Union legislature and before the ECJ as the Union's constitutional court.

Redistribution through welfare state measures would not be possible without sufficient fiscal resources. A central principle of the European macroeconomic constitution is Member State fiscal sovereignty, including the right of taxation. The Eurozone crisis has opened inroads into Member State sovereignty, but the decisive step in the direction of Europeanizing fiscal policy and building 
up Union fiscal capacity has not been taken. Hence, the EU simply does not possess the indispensable fiscal means to act as a transnational welfare state, nor is a fiscal union a likely prospect for the foreseeable future. For the German Constitutional Court, for instance, the inextricably intertwined fiscal and social policy competences belong to the core area of national sovereignty which democracy, as an inviolable principle of the national constitution, prohibits from being transferred to the transnational level. ${ }^{3}$

Even where the EU possesses legislative social policy competences, their use outside the coordination of cross-border social security and healthcare has been scarce. Reaching necessary consensus on legislative measures, in particular outside such fields of 'encapsulated federalism' as labour law and antidiscrimination law, ${ }^{4}$ is extremely difficult due to Member State sovereignty concerns; the cultural, ideological, institutional and financial variance of national social policy regimes; and economic divergences - all greatly accentuated by the eastern enlargement. This is also the backdrop to the structural asymmetry in the EU which favours judicial lawmaking over political lawmaking and negative integration over positive integration (Scharpf 1999; 2010). It also explains why European social policy, especially in fields central for national welfare states, is a favoured province of the open method of coordination, conferring on it a voluntaristic label (Streeck 1995; on the open method of coordination in the social dimension, see Armstrong 2010).

\section{$<$ a RESTRICTIONS ON FREE MOVEMENT}

The microeconomic constitution may impose limitations on national welfare regimes in two ways: first, by treating national social policy measures as restrictions on free movement or competition 
and, secondly, by subjecting national welfare services themselves to internal market law. The jurisprudence of the ECJ has been crucial in staking out the boundaries of Member State sovereignty in social policy. Through the prism of negative integration, the Court has examined Member State socially oriented legislation as a potential restriction of fundamental economic freedoms or undistorted competition. The Dassonville formula of the ECJ adopted a wide definition of the national measures which could have an effect equivalent to that of quantitative restrictions on the free movement of goods. The definition encompassed the following: 'all trading rules enacted by Member States which are capable of hindering, directly or indirectly, actually or potentially, intra-community trade are to be considered as measures having an effect equivalent to quantitative restrictions'. ${ }^{5}$ Through the Dassonville doctrine, the ECJ extended its constitutional jurisdiction to socially motivated national legislation in the fields of, say, consumer or worker protection or public health, where the Community at the moment, did not enjoy legislative competence. Judicial legislation pursuing negative integration did not acknowledge the boundaries of legislative competence for positive integration. ${ }^{6}$

On the other hand, the mandatory requirements which, under Cassis de Dijon, define acceptable Member State justifications for restricting the free movement of goods, include 'in particular [... ] the effectiveness of fiscal supervision, the protection of public health, the fairness of commercial transactions and the defence of the consumer' (Para. 8). ${ }^{7}$ Even if social rights or other social viewpoints were not expressly invoked in Cassis de Dijon, the ECJ may still recognize them as mandatory requirements. Indeed, especially after Maastricht, the ECJ has conceded the relevance of social policy justifications. However, in line with other mandatory requirements, social 
viewpoints have yet to prove their force in the proportionality test - $a$ 'cost-benefit' assessment which constitutes the final phase in the Court's argument. ${ }^{8}$

In the field of services, too, the ECJ has established itself as a constitutional court, competent to assess the impact that socially oriented legislation or comparable measures may have on free movement. However, to counterbalance a rather extensive definition of restrictions on free movement, the Court again went beyond the wording of the Treaty in defining acceptable Member State justifications under the heading of imperative reasons.

$<$ a THE EXTENSION OF INTERNAL MARKET LAW TO WELFARE SERVICES

Censuring national social legislation for restricting free movement and infringing on trade union freedom of action may justly be seen as limiting Member State social policy sovereignty and the right to decide on the regime through which that sovereignty is exercised. Still, a potentially much more serious threat to Member State autonomy in choosing the national welfare model arises from subjecting healthcare and social security themselves to free movement and competition law. The ECJ's attention to services since the late 1980s has not excepted social security or healthcare. In its rulings, the ECJ habitually refers to Treaty provisions confirming Member State sovereignty in these crucial areas of national welfare regimes. However, the Court has not considered the provisions an obstacle to the application of free movement or competition law. This has cleared the ground for the primacy of the economic constitution over the social constitution and for a corresponding internal hierarchy in Treaty law. ${ }^{9}$ 
In applying free movement or competition law to welfare services, the first issue concerns the qualification of the service involved: is it an economic service for the purposes of free movement and competition law? An important string of healthcare cases has dealt with cross-border healthcare, more specifically, the right of a patient to reimbursement from the social security scheme of her or his country of affiliation for treatment received in another Member State. In a number of cases, the Court has held that both ambulatory healthcare and treatment received in hospital are services subject to free movement legislation. After affirming the applicability of free movement law, the Court has proceeded to discuss the refusal of reimbursement as a potential restriction on the freedom to provide - and receive - services. The fact that the country of affiliation has adopted a national health service (NHS) system, based on publicly owned hospitals providing a health service either free of charge or for symbolic compensation, does not affect the relevance of the freedom of movement law for cross-border healthcare. What is essential is the character of the service received in the other Member State. Services in the NHS system are not of an economic character, nor are public hospitals providing them undertakings for the purposes of competition law. ${ }^{10}$ As we shall see below, this does not, however, relieve the NHS country from its obligation to reimburse the costs of healthcare services of an economic nature received in another Member State.

The need to locate social security schemes with regard to the boundary separating non-economic services from economic services has arisen in cases where a person or a company covered by a compulsory scheme has refused to pay a contribution, claiming that its compulsoriness violates constitutional competition law. Starting from Poucet and Pistre, ${ }_{11}^{11}$ the ECJ has developed a set of yardsticks for judging whether or not a social security fund is an undertaking and subject to 
competition law. The Court has argued that as social purposes can be realized through economic, market-oriented and non-economic action, a social purpose as such does not exempt a fund from the application of competition law. What appears to be the decisive criterion for exemption is the solidarity principle adhered to in financing the scheme and determining the benefits. Solidarity may take diverse forms. It may be internal and confined to the clients of the fund, that is, its beneficiaries and contributors. It may also extend beyond clients and be manifest in external subsidies from the state - from taxes or other funds. Crucial for both internal and external solidarity is that financing is not based on capitalization ${ }^{12}$ and that the benefits which clients receive are not directly linked to their contributions.

The provisions in Art. 106 TFEU (previously Art. 90 TEC) lay down a general prohibition for Member States from enacting or maintaining in force any measure concerning public undertakings and undertakings with special or exclusive rights which would be contrary to Treaty rules, in particular competition law and the prohibition of discrimination on the basis of nationality. If the Court has found a social security fund to be an undertaking, it has moved to examining whether the compulsoriness of the scheme amounts to an exclusive right within the meaning of Art. 106(1) TFEU and, if it does, whether it constitutes an unjustified restriction on competition. Art. 106(2) TFEU allows restricting competition in favour of 'undertakings entrusted with the operation of services of general economic interest' if restrictions are necessitated by the particular tasks assigned to the undertakings. In Albany, the Court held it to be decisive whether the exclusive right of a social security fund and the ensuing restriction on competition are 'necessary for the performance of a particular social task of general interest with which that fund has been charged'.13 
A social function or financial solidarity fund have not sufficed to exclude a social security scheme from the concept of undertaking. By contrast, the Court has deemed these features relevant when assessing the justifiability of a restriction of competition deriving from the compulsoriness of a social security scheme. In Albany, the Court first invoked the essential social function that the supplementary pension scheme under scrutiny fulfilled within the pension system of the country concerned. Secondly, in the Court's assessment, the fund displayed a high level of (financial) solidarity which rendered its services less competitive than comparable services provided by insurance companies and went towards justifying its exclusive right. The Court inferred that 'the removal of the exclusive right conferred on the Fund might make it impossible for it to perform the tasks of general economic interest entrusted to it under economically acceptable conditions and threaten its financial equilibrium'.

Bringing social security schemes under the concept of services of general economic interest, employed by the Treaty provision now in Art. 106(2) TFEU, may seem somewhat surprising. The standard reading of the concept mainly invokes infrastructure services which are vital for the economy in general, such as telecommunications and other network industries or postal and transport services. It is hard to avoid the impression that, in order to promote the application of the microeconomic constitution to services, the Court has preferred to employ a wide definition of both economic activity and undertaking but, as a counterbalance, has also wanted to acknowledge the relevance of solidarity-related justifications for compulsory social security schemes. This has required a liberal interpretation of 'services of general economic interest' and exemption from the constraints of competition law facilitated by the Treaty. 
In many Member States, services-related ECJ jurisprudence raised concerns about their sovereignty over the organization and financing of core welfare services. The amendments which the constitutional legislator introduced through the Treaty of Amsterdam reflect these concerns. Yet, they did not diffuse the conceptual haziness surrounding welfare services, rather the contrary. The Treaty included services of general economic interest among the shared values of the Union and pointed to their role in strengthening social and territorial cohesion. It also obliged the Union and the Member States to secure that 'such services operate on the basis of principles and conditions, particularly economic and financial conditions, which enable them to fulfil their missions' (Art. 16 TEC-Amsterdam). The Lisbon Treaty amended this provision by entrusting the ordinary legislator with the task to 'establish these principles and set these conditions without prejudice to the competence of Member States, in compliance with the Treaties, to provide, to commission and to fund such services' (Art. 14 TFEU).

In its effort to ensure the implementation of free market and competition law in the service sector, the Court has enjoyed the support of the Commission, expressed in Commission communications and legislative initiatives, largely aiming at codifying the jurisprudence of the Court. The most debated legislative initiatives have been the proposals for the 2006 Services Directive and the 2011 Patients' Rights Directive. Several Member States pushed to exclude welfare services from the Services Directive. In the end, healthcare was explicitly left out but social security schemes were not: if they meet the criteria of economic services, the Directive is relevant. As regards healthcare, the Preamble to the Services Directive states that cross-border healthcare would be addressed in another legal instrument (Recital 21). That instrument turned out to be the 
Patients' Rights Directive. ${ }^{14}$ Both directives were issued under Art. 114 TFEU allowing harmonization for the purpose of the establishment or functioning of the internal market. This manifests the fact that a central backdrop to both the Services Directive and the Patients' Rights Directive is furthering economic integration and implementing the microeconomic constitution, rather than distinct social policy considerations.

$<$ a WWLFARE SERVICES FOR MOBILE WORKERS AND CITIZENS

In the negotiations paving the way for the Treaty of Rome, the harmonization of social security was expressly rejected and the Community was only granted legislative competence (even for coordinating national social security) to the extent deemed necessary for establishing the common market (Barnard 2011, pp. 642-5). Coordination did not aim at distinct social aims but was seen in instrumental terms, as a means serving economic integration. The only specific social legislative competence in the Treaty was located in the Free Movement title, not in the Social Policy title, that is, it was located among the provisions of economic constitutional law rather than social constitutional law. The instrumental tone is conspicuous in the wording of Art. 51 TEEC (now Art. 48 TFEU), which obliged the Community legislator to adopt 'such measures in the field of social security as are necessary to provide freedom of movement for workers'.

The wording implies that the provision does not possess direct effect but presupposes secondary legislation. However, the expansion of direct effect has encompassed provisions on the free movement of workers as well. The Court has adopted an extensive interpretation of both the personal and substantive scope of the central legislative instrument issued under Art. 51 of the 
Treaty of Rome: Social Security Regulation $1408 / 71 .{ }^{15}$ The Court gradually expanded the personal reach of the Regulation from migrant workers and their dependants to all economically active persons, as well as future and former workers, such as students and pensioners. In the Court's interpretation, the substantive scope, in turn, comprises not only traditional 'Bismarckian' labourrelated benefits, mostly of a contributory character, but reaches out to non-contributory benefits as well.

Originally, the Leitbild of social security coordination was the mobile worker. ${ }^{16}$ The inclusion of students in the early 1990s already diverged from that initial Leitbild, but the decisive turning point came with the introduction of European citizenship in Maastricht. The mobile European citizen emerged as the new dominant Leitbild, guiding the cross-border right to social security. In spite of the loosening of dependence on the economic constitution, this development did not signal a triumph of 'genuine' social policy objectives. Even after the citizenship turn, social policy was devised on premises other than social policy premises, and again, the coordination of social security schemes was conceived of in instrumental terms. Now the general aim was to promote mobility, not merely of economically active persons for the sake of economic integration but of European citizens in general for the sake of broader societal integration. Acting as a constitutional court, the Court, in its case law on cross-border social security rights set aside Regulation 1408/71 and invoked the right of EU citizens 'to move and reside freely within the territory of the Member States', explicitly enshrined in the Treaty (now Art. 21(2) TFEU). As the ECJ ruled in Baumbast, ${ }^{17}$ this Treaty provision possesses a direct effect; hence, the realization of the citizenship's right of free movement does not depend on secondary legislation. When an EU citizen exercises the Treaty-based right of movement, this brings her or him within the scope of the Treaty provision 
prohibiting discrimination on the grounds of nationality (now Art. 18 TFEU) as well. This line of argument opened access for mobile European citizens to social security benefits in their Member State of residence. However, the Court has also shown understanding towards the Member States' wish to ward off 'welfare tourism' and the consequent strain on their welfare systems. The Court has made the eligibility of foreign nationals for social benefits dependent on additional criteria, reflecting the firmness of the bond with the state of residence. Still, all restrictions on the social rights of mobile citizens are subject to a proportionality test, which ultimately decides their justifiability.

The substantive reach of the right to social benefits derived from European citizenship is larger than the cross-border rights granted under Art. 51 of the Treaty of Rome and the Social Security Regulation. It covers, in principle, all social benefits, including social assistance, which was expressly excluded from the scope of Regulation 1408/71. The constitutional basis is different too. Diverging from workers' rights to social benefits, the Treaty does not explicitly presuppose secondary legislation on citizenship rights. Still, complementary secondary legislation has been issued on citizens' freedom of movement and adjacent rights to social benefits too. Secondary legislation, though, does 'little more than codify the jurisprudence of the European Court of Justice' (Damjanović and de Witte 2009). The Court has formulated its doctrines as a constitutional court and based them directly on the Treaty so that the doctrines narrow the leeway of the political legislator. Furthermore, because of the direct effect of the Treaty provisions on citizenship, the freedom of movement and non-discrimination, the list of rights expressly guaranteed to citizens by secondary legislation is not necessarily exhaustive.

Healthcare belongs to the core welfare areas to which Member States have been especially attentive to their sovereignty and to which the clear emphasis in Union policy lies in soft law and 
the open method of coordination. The coordination of cross-border healthcare is an exception to this rule and constitutes a parallel case to the coordination of social security. Again, social policy decisions have been taken outside the Treaty framework for social policy, primarily on premises other than social policy premises. And again, the institutional driving force has been the ECJ while the contribution of the political legislator has mainly been reduced to codifying case law. The Treaty basis for the Court's activism has, though, been different. Instead of the provisions for worker or citizen mobility, the primary Treaty support has been the provision of the freedom to provide services (now Art. 56 TFEU).

As long ago as 1984, in Luisi and Carbone, the ECJ established that the Treaty-guaranteed freedom to provide services implies the freedom to receive them. ${ }^{18}$ Still, in cross-border healthcare the main legal issue has not been freedom to receive healthcare services in another Member State as such, but the obligation of the home country to reimburse those services from its public insurance system. In 1998 in Kohll and Decker, ${ }^{19}$ the Court ruled that healthcare funded by a public insurance system is covered by free movement law. EU citizens are entitled as service recipients to crossborder healthcare financed by their home country's insurance system, provided that the service in question is in general covered by that system. Acting once more as a constitutional court, the ECJ set aside the restrictions that Regulation 1408/71 imposed on the export of healthcare benefits and based its rulings directly on Treaty law on free movement. Subsequently, the Court has specified the main principles defining cross-border access to healthcare services, thereby progressively adjusting and widening the conditions originally laid down by the legislator in Regulation $1408 / 71$. The Court has formulated all the crucial parameters of the scope, conditions and funding of cross-border healthcare. Again, what has remained for the Union legislator is codification of case law; this was accomplished through the Patients' Rights Directive. 
<a>THE DENATIONALIZATION AND DETERRITORIALIZATION OF WELFARE SERVICES

As many observers have remarked, the expansion of rights to cross-boundary welfare services has led to a tendency to denationalize and deterritorialize national welfare regimes. Depending on the chosen welfare model, this tendency can have grave consequences for national social policy (see in particular Martinsen (2005a; 2005b); and Menéndez (2009)). The familiar groupings of European welfare states, starting from Esping-Andersen's typology, are of limited help in analysing potential consequences. Instead, what is decisive is the method of financing and organizing social and healthcare services. In healthcare, the main dividing line goes between the NHS and insurancebased systems. In the former, healthcare services are publicly funded and delivered, while patients merely pay nominal or symbolic remuneration. In the latter, public insurance schemes reimburse the costs of publicly or privately delivered and financed services to patients. In social security, a related distinction separates residence-based systems from insurance-based systems. In a residence-based model, a person is entitled to social benefits on the basis of citizenship or habitual residence. Most benefits are not dependent on individual contributions but are universally granted and financed through taxation. In a social insurance model, employees are insured against basic risks in accordance with lex loci laboris. Social benefits are primarily financed by and depend on individual contributions (Martinsen 2005a, pp. 1038-9). In practice, distinctions between the NHS and insurance-based healthcare or residence-based and insurance-based social security are not necessarily clear cut, so that one and the same system may combine features from both sides of the dividing line. 
In its rulings on cross-border social security and healthcare the ECJ routinely pays lip service to Member State sovereignty in choosing welfare models. Still, denationalization and deterritorialization evidently affect different models in different ways. Denationalization manifests itself in the opening of national welfare services for non-nationals: first, for mobile workers and their family members, then for other economically active nationals of other Member States moving across borders and, finally, for all European citizens exercising their Treaty-based right of movement. This has had repercussions, particularly for residence-based social security, a traditional hallmark of Nordic welfare states which have been forced to modify their rules on eligibility for social security benefits, above all, in order to drop the nationality requirement in order to fall within the scope of the Social Security Regulation. Furthermore, Member States have been obliged to extend the coverage of both the NHS and insurance-based systems of public healthcare beyond their own nationals and long-time residents.

Denationalization is supplemented by deterritorialization. If denationalization has opened national social security and healthcare systems for non-nationals, deterritorialization has allowed the participants of national systems to receive social security benefits or healthcare services in other Member States. Regulation 1408/71 adopted the principle of exportation within its field of application and facilitated cross-border healthcare, but only after authorization by the Member State of affiliation. The case law of the ECJ, starting with Kohll and Decker and codified in the Patients' Rights Directive, gradually expanded the possibility of exit; in other words, it facilitated searching for healthcare in another Member State than the country of affiliation. If residencebased models have been under particular pressure in social security, in healthcare, compared to the NHS system, insurance-based systems are more easily adaptable to the combined effects of 
the expanded possibilities of the entry of patients from other Member States and the exit of patients covered by the national system.

Denationalization and deterritorialization have been accompanied by EU-induced amendments to national legislation and modifications in national social security or healthcare models. Still, indirect impacts may be more important than legal obligations in introducing changes to national welfare regimes. EU law does not oblige Member States to revise their fundamental choices between residence- and insurance-based social security or between NHS and insurance-based healthcare. But, arguably, insurance-based social security and healthcare can be more flexibly geared up for the liberalization driven by the Court and the Commission. Liberalization backed up by ECJ constitutional jurisprudence has given a boost to those trends in organizing and financing welfare services, which the Commission, in its 2006 Communication, labels modernization ${ }^{20}$ and which Gareth Davies has characterized as a shift from provision to regulation (Davies 2006, p. 53). Denationalization and deterritorialization may influence the substantive reach and level of welfare services too. The prospect of non-nationals entering publicly financed welfare regimes with the ensuing additional financial burdens or the enlarged territorial exit of nationals at the expense of the Member State of affiliation may function as an efficient brake to introducing new benefits, or enlarging the scope or raising the level of existing ones. Instead of upgrading, the general tendency in Member States seems rather to be towards downgrading.

At the most fundamental level, denationalization and deterritorialization may strike at the solidarity foundations of national welfare regimes. Solidarity is a polysemic term that also has diverse conceptual meanings. In healthcare, NHS and insurance-based systems are both premised 
on solidarity in the sense of both financial redistribution and an underlying socio-ethical bond. In social security, financial solidarity is evident in both residence- and insurance-based systems. By contrast, solidarity in the socio-ethical sense is more manifest in a residence-based system than in an insurance-based system. This is due to the bounded nature of the solidarity, which has underlain national welfare state projects: a solidarity uniting the nationals living in the territory of a nation state. The future of the social dimension in Europe is overshadowed by the danger that denationalization and deterritorialization will undermine the ethical and sociological foundations of national welfare states without initiating compensating developments at the European level (see also Menéndez 2009).

Denationalization and deterritorialization expand financial solidarity beyond national citizenry and territory. This may corrode the socio-ethical solidarity which made financial solidarity - and the welfare state in general - possible in the first place. Of course, no a priori obstacles exist to extending the boundaries of the solidarity community too. But this cannot be done overnight, by fiat, and requires arduous social and cultural developments. Here, European integration still has a long way to go.

$<$ a>THE CONSEQUENCES OF MACROECONOMIC CONSTITUTIONALIZATION

European macroeconomic constitutionalization, launched in Maastricht, has further curtailed Member State leeway in social policy. Due to the close intertwinement of redistributive social policy with fiscal policy, the fiscal constraints introduced by the Maastricht EMU provisions, and significantly reinforced as a reaction to the Eurozone crisis, have reduced the latitude for national social policy too. 
A common currency in a non-optimal currency area calls for high labour market flexibility. Because of limited labour mobility and intra-euro-area fiscal transfers, increasing labour market and wage flexibility has been deemed necessary in order to manage the adverse country-specific developments which common monetary policy cannot address. Indeed, during the Eurozone crisis measures aimed at enhancing labour market and wage flexibility were a staple in the Memoranda of Understanding, implementing the strict conditionality of financial assistance. The crisis provided new impetus to the market liberal tenets of marketization and flexibilization as central premises of European macroeconomic governance. The effects of official market liberalism are not confined to the crisis states but extend to the Eurozone as a whole. These developments are an important aspect of the shift in emphasis between liberal and social market economies towards the former (Scharpf 2010), a shift which questions the constitutional principle of EU neutrality with regard to 'varieties of capitalism'.

In addition to the requirements of labour market and wage-setting liberalization and flexibilization, austerity programmes have curbed the social policy sovereignty of crisis states through detailed and focused obligations to cut social expenditure and public sector wages (Busch et al. 2013). ${ }^{21}$ Indeed, social spending has been a major target in measures aiming to reduce the budget deficit and public debt. The massive impact of European measures on the labour and welfare regime of, in particular, the crisis states raises the question of the protective role of social rights. The ECJ has been wary of basing its rulings on either the European Social Charter of the Council of Europe or the solidarity provisions in the CFREU. So, the position of social rights in EU

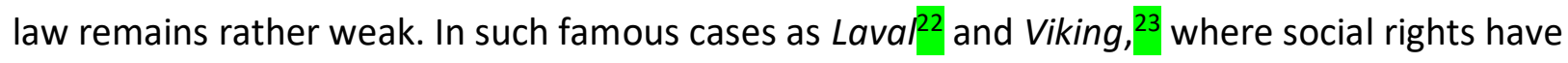


clashed with rights emanating from fundamental freedoms, the social dimension has rested on Member State law. Despite the rather weak position of social rights in EU law, it would be erroneous to label them as merely constitutional soft law.

The renewed European Charter of Social Rights belongs to the common constitutional heritage which, in accordance with Art. 6(3) TEU, determines the contents of fundamental rights as general principles of EU law. What is even more important is that the provisions on solidarity rights of the EU Charter, similarly to other Charter provisions, are legally effective and 'addressed to the institutions, bodies, offices and agencies of the Union' so that these bodies are to 'respect the rights, observe the principles and promote the application thereof in accordance with their respective powers' (Art. 51(1) CFREU).

According to the prevalent view of social rights - manifest in, for instance, the so-called Limburg principles - in times of austerity, social rights function as criteria for prioritization in the allocation of spending cuts. ${ }^{24}$ Yet almost no reference to either the Solidarity chapter of the CFREU or to the renewed European Social Charter can be found in the abundant legal documents which the Eurozone crisis produced. In the face of the failure of fundamental rights monitoring within the EU, other transnational or international supervisory bodies have had to step in. These, however, possess less influence and have no jurisdiction over Union action or intergovernmental stability mechanisms. All they can do is criticize national authorities which have had but little latitude in implementing the strict conditionality imposed on them (Tuori and Tuori 2014, pp. 239-40). Within the crisis states, austerity measures and labour market reforms have led to litigation before national courts. In general, the results have been meagre. The courts have exercised judicial 
restraint and displayed far-going understanding of government defences invoking economic emergency and the strict conditionality of financial assistance.

In sum, social rights have proven rather toothless in resisting or redirecting spending cuts or structural labour market reforms, weakening the position of social partners and collective bargaining. This general conclusion covers all levels of social rights protection, whether European, international or national. With regard to the conditionality of European financial stability assistance, the primary deficiency is a lack of a Union-level monitoring mechanism and the apparently non-existent commitment of key Union institutions.

$<$ C >TWO NOTIONS OF JUSTICE - ARE THEY COMPLEMENTARY OR CONFLICTING?

In many respects, Union social policy measures reverse the order of binaries typical of national welfare states. In the context of national welfare states, we are used to thinking of social policy in terms of market correction and decommodification. By contrast, in the EU social policy, too, seems to be subjected to the purposes of market construction, promoting commodification rather than decommodification. In this section I discuss another reversal: that of the centre and periphery.

The credo of the national welfare state is to guarantee basic welfare services, such as social security and healthcare, to the citizenry as a whole. If in general one is entitled to talk about an independent EU contribution to social policy, its focus lies elsewhere than on redistributive services in the kernel of national welfare regimes; rather, its focus lies on regulatory measures in their outer ring. Instead of an emphasis on redistribution, it is on regulation: on regulatory private 
law. Diverging from the standard situation at state level, in the EU this branch of law, too, is constitutionally anchored. Four particular fields of regulatory private law have gradually stood out: labour law, consumer law, antidiscrimination law and law on universal services. In these fields, European law has advanced to positive integration through harmonization of Member State legislation. The political legislator has played a central role, although in antidiscrimination law in particular the ECJ has also been able to assert itself. Compared to market-constructing negative integration through judicial legislation or the equally market-constructing coordination of crossborder social security and healthcare, positive integration through regulatory private law has gained greater independence from the logic of economic constitutionalization. European regulatory private law may seem a heterogeneous legal branch but this would be a false impression: European regulatory private law is united by a social orientation and by a particular conception of justice which sets it apart from typical national welfare state legislation (what HansW. Micklitz (2011a; 2011b) has termed access justice).

In the social dimension, the tasks assigned respectively to the markets, the Member States and the Union may be informed by three alternative, ideal typical notions of justice. The first of these is market justice or allocative justice: whatever is the outcome of market mechanisms is just. Here the role of the state or the transnational polity is reduced to securing the general framework conditions for market mechanisms, such as the rights to property and freedom of contract. This is the realm of F.A. Hayek's (1982) rules of just conduct or Robert Nozick's (1975) libertarianism. The second alternative is access justice (as Micklitz has defined it). As a rule, functioning markets do not emerge spontaneously but presuppose particular market-constructing measures by a polity. Furthermore, left to themselves, market mechanisms may lead to self-detrimental results by 
eliminating some economic agents from the marketplace and barring the (re-)entry of others. Public policy that promotes access justice furthers market construction, combats exclusion and seeks to facilitate the (re-)entry of economic agents to the marketplace as entrepreneurs, workers or consumers. The third alternative is social justice, which implies the correction of the distributive outcomes of the markets and, obviously, presupposes solidarity in both a financial and a socioethical sense.

Libertarian market justice entails a minimum state with practically no social responsibilities; a social constitution based on market justice would be a contradiction in terms. The value basis of national welfare states, with their emphasis on social security and healthcare, consists of solidaristic social justice. By contrast, EU social law is largely tailored to pursue not redistributive social justice but access justice, facilitating (re-)entry to the marketplace. This objective is conspicuous in regulatory private law, especially in labour law, consumer law and law on universal services but also in those parts of antidiscrimination law which address market participation. It is evident in the coordination of cross-border social security and healthcare as well. The citizenship turn, though, has modified the determinants of access justice: now at issue is access to wider societal integration, redemption of the promise of European citizenship and the realization of free movement of citizens. In turn, judicial and political legislation on cross-border healthcare purport to guarantee access to services for migrant patients, that is, their entry to the transnational marketplace of healthcare services.

The prevalence of access justice in EU social policy can be deemed yet another example of the primacy of the economic constitution over the social constitution. Market-constructing or market- 
maintaining social policy, manifesting access justice, supports the market-constructing and market-maintaining function of economic constitutional law. If we try to identify the conception of justice underlying the microeconomic constitution, centred on free movement and competition law, this would fall under access justice. Free movement law is supposed to create Europe-wide markets and to eradicate obstacles which national policy measures might pose to that objective. In turn, competition law aims to prevent the accumulation of private power which would distort the functioning of market mechanisms and shut out competitors on illegitimate grounds or prevent the entry of new market participants.

Are national, solidaristic social justice and transnational access justice complementary or conflicting principles? European regulatory private law does not affect the workings of core welfare services, which are left to the care of Member States. The fundamental social compact underlying European economic integration also intimates a complementary relation between the two conceptions of justice: transnational markets were supposed to produce increased prosperity, while national redistributive mechanisms were supposed to ensure just allotment of that prosperity. But things have not turned out to be so simple. Often enough, conflicts between economic constitutional law and national social legislation can be recategorized as conflicts between two types of rights - transnational economic rights established by free movement law and national social rights - and two notions of justice: transnational access justice and national, solidaristic social justice. This is one way of depicting the essential issue in, say, Viking and Laval. The access justice of the freedom of the establishment and free movement of services collided with, and finally prevailed over, the Nordic welfare model (that is, the Nordic regime for promoting solidaristic social justice). We have perceived an analogous tension permeating the 
case law on cross-border healthcare; guaranteeing access to cross-border services for mobile patients through the obligation of reimbursement by the country of affiliation may jeopardize the solidaristic foundations of national healthcare. Similar consequences may ensue from cross-border social security, the coverage of which has expanded from mobile workers and their dependants to mobile citizens and the subjection of social security funds to competition law. The denationalization and deterritorialization of social security and healthcare in the name of access justice may jeopardize the solidaristic basis of national welfare regimes.

Whether or not Union social rights will attain a role in the defence of national welfare regimes remains to be seen. The fact that they have been almost totally ignored by both EU institutions and Member States as a potential counterweight to the implications of the macroeconomic constitution during the recent Eurozone crisis does not give reason for much optimism among the defenders of social rights.

$<$ a $>$ NOTES

<Typesetter: please insert notes 1-24 here>

* A more detailed version of my argument may be found in K. Tuori (2015) pp. 227-68.

${ }^{1}$ Case C-36/02 Omega Spielhallen [2004] ECR I-9609; Case C-112/00 Schmidberger [2003] ECR I5659; Case C-438/05 International Transport Workers' Federation and Finnish Seamen's Union [2007] ECR I-10779; Case C-341/05 Laval un Partneri [2007] ECR I-11767. 
${ }^{2}$ BVerfG, 2 BvE 2/08, 30 June 2009, Para. 252.

${ }^{3}$ BVerfG, 2 BvE 2/08, 30 June 2009, Absatz-Nr. (1-421).

${ }^{4}$ The term 'encapsulated federalism' is used by W. Streeck (1995).

${ }^{5}$ Case C-8/74 Dassonville [1974] ECR 837, Para. 5.

${ }^{6}$ Of course, the Court has not always ruled against national legislation, as, for instance, Sunday Trading case law proves (see H.-W. Micklitz 2005).

${ }^{7}$ Case C-120/78 Rewe v. Bundesmonopolverwaltung für Branntwein [1979] ECR 649 (Cassis de Dijon), Para 8. Cassis de Dijon is memorable for introducing not only the doctrine of mandatory requirements but also mutual recognition. The latter doctrine opened the way for regulatory competition among Member States with its potential 'horizontal' impact on national welfare regimes.

${ }^{8}$ See the formula in Case C-55/94 Gebhard v. Consiglio dell'Ordine degli Avvocati e Procuratori di Milano [1995] ECR I-4165, Para. 37.

${ }^{9}$ See, e.g. Case C-372/04 Watts v. Bedford Primary Care Trust and Secretary of State for Health [2006] ECR I-04325, Paras 146-7, and Case C-157/99 Geraets-Smits v. Stichting Ziekenfonds and Peerbooms v. Stichting CZ Groep Zorgverzekeringen [2001] ECR I-0473, Paras 44-5.

${ }^{10}$ Case T-319/99 FENIN [2003] ECR II-357, Paras 39-40.

11 Joined Cases C-159/91 and C-160/91 Poucet v. Assurances Générales de France and Caisse Mutuelle Régionale du Languedoc-Roussillon, and Pistre v. Caisse Autonome Nationale de Compensation de l'Assurance Vieillesse des Artisans [1993] ECR I-637.

12 In the Court's case law capitalization refers to the dependence of entitlements on contributions paid and the financial results of the scheme. 
${ }^{13}$ Case C-67/96 Albany International BV v. Stichting Bedrijfspensioenfonds Textielindustrie, with joined Cases C-115/97, C-116/97 and C-117/97 [1999] ECR I-5751, Para. 98.

14 Directive No. 2006/123 of 12 December 2006 on services in the internal market [2006] OJ L376/36; Directive No. 2011/24 of 9 March 2011 on the application of patients' rights in crossborder healthcare, [2011] OJ L88/45.

${ }^{15}$ Council Regulation No. 1408/71 of 14 June 1971 on the application of social security schemes to employed persons and their families moving within the Community, [1971] OJ L149/2.

${ }^{16}$ I have borrowed the term Leitbild from H.-W. Micklitz (2011a).

${ }^{17}$ Case C-413/99 Baumbast and R v. Secretary of State for the Home Department [2002] ECR I7091.

18 Joined Cases C-286/82 26/83 Luisi and Carbone v. Ministero del Tesoro [1984] ECR 377.

${ }^{19}$ Case C-120/95 Decker v. Caisse de maladie des employés privés [1998] ECR I-1831; Case C-158/96 Kohll v. Union des caisses de maladie [1998] ECR I-1931.

${ }^{20}$ Communication from the Commission: Implementing the Community Lisbon programme Social services of general interest in the European Union $\{\operatorname{SEC}(2006) 516\} \operatorname{COM}(2006) 177$ final.

${ }^{21}$ For an analysis of Greek measures see A. Koukiadaki and L. Kretsos (2012).

${ }^{22}$ C-341/05 Laval un Partneri [2007] ECR I-11767.

${ }^{23}$ C-438/05 International Transport Workers' Federation and Finnish Seamen's Union [2007] ECR I10779.

${ }^{24}$ Limburg Principles on the Implementation of the International Covenant on Economic, Social and Cultural Rights, UN Doc. E/CN.4/1987/17, available in Human Rights Quarterly (1987). 
$<$ a $>$ BIBLIOGRAPHY

Armstrong, Kenneth A. (2010), Governing Social Inclusion: Europeanization through Policy Coordination, Oxford: Oxford University Press.

Barnard, Catherine (2011), 'EU “Social” Policy: From Employment Law to Labour Market Reform' in Paul Graig and Gráinne de Búrca (eds), The Evolution of EU Law, 2nd ed., Oxford: Oxford University Press., pp. 641-86.

Busch, K., C. Hermann, K. Hinrichs and T. Schulten (2013), 'Euro Crisis, Austerity Policy and the European Social Model: How Crisis Policies in Southern Europe Threaten the EU's Social Dimension'. Friedrich Ebert Stiftung.

Communication from the Commission: Implementing the Community Lisbon programme - Social services of general interest in the European Union $\{\operatorname{SEC}(2006) 516\} \operatorname{COM}(2006) 177$ final.

Damjanović, D. and B. de Witte (2009), 'Welfare Integration through EU Law: The Overall Picture in the Light of the Lisbon Treaty' in U.B. Neergaard, R. Nielsen and L.M. Roseberry (eds), Integrating Welfare Functions into EU Law: From Rome to Lisbon, Copenhagen: DJфF Publishing, pp. 52-97.

Davies, G. (2006), 'The Process and Side-effects of Harmonisation of European Welfare States', NY, U School of Law, Jean Monnet Working Paper 02/06.

Esping-Andersen, G. (1990), The Three Worlds of Welfare Capitalism, Princeton: Princeton University Press.

Hayek, F.A. (1982), Law, Legislation, and Liberty, vol 1, London: Routledge and Kegan Paul. Koukiadaki, A.L. and Kretsos (2012), 'Opening Pandora 's Box: The Sovereign Debt Crisis and Labour Market Regulation in Greece', Industrial Law Journal 41 (3), 276-304.

Martinsen, D.S. (2005a), 'The Europeanization of Welfare: The Domestic Impact of Intra-European Social Security', Journal of Common Market Studies 43 (5), 1027-54.

Martinsen, D.S. (2005b), 'Towards an International Health Market with the European Court', West European Politics 28 (5), 1035-56.

Menéndez, A.J. (2009), 'European Citizenship after Martínez Sala and Baumbast: Has European Law Become More Human but Less Social?', Oslo: ARENA Working Paper No. 11. 
Micklitz H.-W. (2005), The Politics of Judicial Co-operation in the EU: Sunday Trading - Equal Treatment and Good Faith, Cambridge: Cambridge University Press.

Micklitz, H.-W. (2011a), 'Introduction: Social Justice and Access Justice in Private Law' in H.-W. Micklitz (ed.), The Many Concepts of Social Justice in European Private Law, Cheltenham, UK and Northampton, MA, USA: Edward Elgar Publishing, pp. 3-6.

Micklitz, H.-W. (2011b), 'Universal Services: Nucleus for a Social European Private Law?' in M. Cremona (ed.), Market Integration and Public Services in the European Union: Collected Courses of the European Academy of Law, Oxford: Oxford University Press, pp. 63-102.

Nozick, R. (1975), Anarchy, State, and Utopia, Oxford: Blackwell.

Scharpf, F.W. (1999), Governing in Europe: Effective and Democratic? Oxford: Oxford University Press.

Scharpf, F.W. (2010), 'The Asymmetry of European Integration, or Why the EU Cannot Be a Social Market Economy', Socio-Economic Review 8 (2), 211-50.

Streeck, W. (1995), ‘Neo-voluntarism: A New European Social Policy Regime’, European Law Journal 1 (1), 31-59.

Tuori, K. (2015), European Constitutionalism, Cambridge: Cambridge University Press.

Tuori, K. and K. Tuori (2014), Eurozone Crisis: A Constitutional Analysis, Cambridge: Cambridge University Press. 